\title{
Picophytoplankton diversity and photoacclimation in the Strait of Sicily (Mediterranean Sea) in summer. I. Mesoscale variations
}

\author{
C. Brunet ${ }^{1, *, * *}$, R. Casotti ${ }^{1, * *}$, V. Vantrepotte ${ }^{2,3}$, F. Corato ${ }^{1}$, F. Conversano ${ }^{1}$ \\ ${ }^{1}$ Stazione Zoologica di Napoli, Villa Comunale, 80121 Napoli, Italy \\ ${ }^{2}$ Université du Littoral, Laboratoire Interdisciplinaire des Sciences de l'Environnement, UPRES-A ELICO 8013, 62930 \\ Wimereux, France \\ ${ }^{3}$ Present address: Joint Research Center, Institute for Environment and Sustainability, 21020 Ispra, Italy
}

\begin{abstract}
Phytoplankton dynamics were investigated at the mesoscale in the northern part of the Strait of Sicily in July-August 1997 on fractionated samples $(<3$ and $>3 \mu \mathrm{m})$ using HPLC pigment analysis and flow cytometry. Distribution, diversity and photoacclimation varied within the different water masses and features present at the time of sampling, including a surface filament of deep, cold water. Picophytoplankton $(<3 \mu \mathrm{m})$ accounted for $80 \%$ of total chlorophyll on average, and was numerically dominated by cyanobacteria of the genus Prochlorococcus, with an average concentration of $5.2 \times 10^{4}$ cells ml $\mathrm{m}^{-1}$. The biomass and pigment diversity of picophytoplankton was higher in the deep chlorophyll maximum (DCM) and was related to hydrological and biological features, whereas larger phytoplankton (>3 $\mathrm{m}$ ) appeared to respond to different cues. Chlorophyll pigment content per cell of Synechococcus spp., Prochlorococcus spp. or picoeukaryotes was estimated by coupling pigment data with flow cytometric counts. In Prochlorococcus spp., we found an average of 0.44 and $1.56 \mathrm{fg}$ divinyl-chlorophyll a (dvchl a) cell ${ }^{-1}$ in surface and DCM layers, respectively. In contrast, chl a content in the picoeukaryote group ranged between 17 and $168 \mathrm{fg}$ chl a cell ${ }^{-1}$, depending upon depth and water mass, which suggested strong photoacclimation and photoadaptation with depth. The relative contribution of each eukaryote pigment to one size class or the other changed through the water column, and reflected size segregation within single taxonomic groups.
\end{abstract}

KEY WORDS: Picophytoplankton · Biodiversity · Deep chlorophyll maximum · DCM · Pigments · HPLC $\cdot$ Flow cytometry $\cdot$ Mesoscale

\section{INTRODUCTION}

The diversity of phytoplankton communities and the dominance of particular populations are the result of numerous factors, including nutrients, light, hydrology and biological factors such as competition (Pemberton et al. 2004). In order to better define the interactions between different parameters and to assess their relative importance, it is necessary to consider the 'traits' of species in communities (Norberg 2004), which are relevant biological parameters that determine responses to the environment. Among these, size represents a key parameter to be consid- ered: it is a strong determinant of ecosystem functioning by influencing, among other things, growth rates, nutrient uptake, buoyancy and response to mixing (Fogg 1991, Prézelin et al. 1991). Indeed, the community structure-as related to size as well as taxonomy-influences both the photophysiology (the focus of this study) and the fraction of new to total production, and is therefore strongly related to ecosystem functioning.

In this study, phytoplankton diversity was investigated using pigment analysis on 2 size fractions: the picophytoplankton $(<3 \mu \mathrm{m}$, Moon-van der Staay et al. 2001) and the nano- and microphytoplankton (>3 $\mu \mathrm{m})$. 
Data from HPLC-pigment analysis were coupled to flow cytometry counts to obtain pigment content per cell, used as an indicator of light adaptation. Using this approach, we were able to separate and to assess the contribution of the picophytoplankton to total community composition, diversity and physiological state, mainly by examining the pigment content and variability per cell. So far, this approach has been used to better characterize the phytoplankton community in terms of chlorophyll or divinyl-chlorophyll (Brunet \& Lizon 2003, Veldhuis \& Kraay 2004), but very few studies have coupled pigment analysis and flow cytometry to describe picoeukaryotes in fractionated samples (Not et al. 2005). Apart from providing insights into their taxonomic diversity as well as their photoacclimation properties, this approach can quantitatively complement information from molecular tools, which have recently revealed the high specific diversity of picoeukaryotes in several marine ecosystems (Moonvan der Staay et al. 2000, 2001, Díez et al. 2001, 2004, Not et al. 2002, 2005).

The study area chosen provided an ideal area to study the interaction of plankton biology with hydrodynamics, because it is a location of active mesoscale dynamics, with recurrent physical structures such as fronts, filaments and meanders (Lermusiaux \& Robinson 2001), which contribute to active biological production. In fact, the Strait of Sicily is known as a biologically rich area and a key site for the Mediterranean Sea in terms of fisheries (Garcia Lafuente et al. 2002, Cuttitta et al. 2003).

In July 1997, a cruise was conducted within the framework of the Synoptic Mesoscale Plankton Experiment (SYMPLEX) project (Bohm et al. 1998), which aimed to investigate phytoplankton dynamics in relation to mesoscale physical features. Multiple stations were sampled across the main features identified at the time of sampling, namely Atlantic Water, Ionian Water, a surface filament and a haline front.

The main aim of this study was to investigate phytoplankton composition and physiological traits in relation to water mass characteristics. In particular, we focused on the picoeukaryote component in terms of diversity and photoacclimation, in order to relate these traits to general dynamics at the mesoscale. Photoacclimation is a key process which optimizes light utilization to allow algal cells to maintain active photosynthesis and growth. The study of photoaclimation provides valuable information at the physiological scale, because photoprotective pigments can affect the quantum yield of photosynthetic carbon fixation (Babin et al. 1996). In addition, at the ecological level, markers of photoacclimation can be used as tracers of vertical movements in the upper layer of the water column (Brunet et al. 2003).
The data obtained provide information on ecosystem functioning and are representative of the Strait of Sicily in summer. Indeed, the community structure in terms of size and taxonomic composition is a strong determinant of photophysiology, which, in turn, is a response to changes in the physical environment. Therefore, these data provide useful insights for the description of ecosystem functioning of the oligotrophic Mediterranean Sea.

\section{MATERIALS AND METHODS}

Sampling. Fifty stations were sampled from 19 July to 1 August 1997 on board RV 'Urania' (Fig. 1). Continuous profiles of temperature, salinity and density were acquired with a CTD probe (SBE 19, Seabird Electronics). Vertical light profiles (photosynthetically active radiation: PAR) were obtained from a spectroradiometer (SPMR, Satlantic) at 12:00 h (local time) on days when the sky was clear.

Discrete water samples were taken at 6 or 8 depths between 5 and $120 \mathrm{~m}$, with a rosette sampler equipped with twenty-four 101 Niskin bottles, for analysis of nutrients, phytoplankton pigments and cell abundance by flow cytometry.

Fig. 1 shows the station locations and the position of a surface filament of cold water, originating from coastal upwelling and wind advection, which is a recurrent feature of this area (Lermusiaux \& Robinson 2001). Water mass classification followed MalanotteRizzoli et al. (1999).

Nutrients. Nitrate, nitrite, silicate and phosphate concentrations were determined on board with fresh samples using the colorimetric procedure of Grasshof (1983).

Flow cytometry. Live samples were analyzed on board using a FACScalibur flow cytometer (Becton Dickinson), equipped with a standard laser and filter set and using $0.22 \mu \mathrm{m}$ filtered seawater as the sheath fluid. Fluorescent beads with a diameter of $0.97 \mu \mathrm{m}$ (Polysciences) were added to each sample as an internal standard, and all parameters were normalized to the beads and expressed as relative units. Data were analyzed using CellQuest software (Becton-Dickinson). Further details are provided in Casotti et al. (2000). Three populations of picophytoplankton were identified and enumerated based upon their scattering and autofluorescence: Prochlorococcus spp. (hereafter Prochlorococcus), Synechococcus spp. (hereafter Synechococcus) and picoeukaryotes (Olson et al. 1993).

In the case of extremely dim Prochlorococcus populations at the surface, the population was assumed to have a normal distribution and the hidden portion was extrapolated, as indicated by Casotti et al. (2003). 

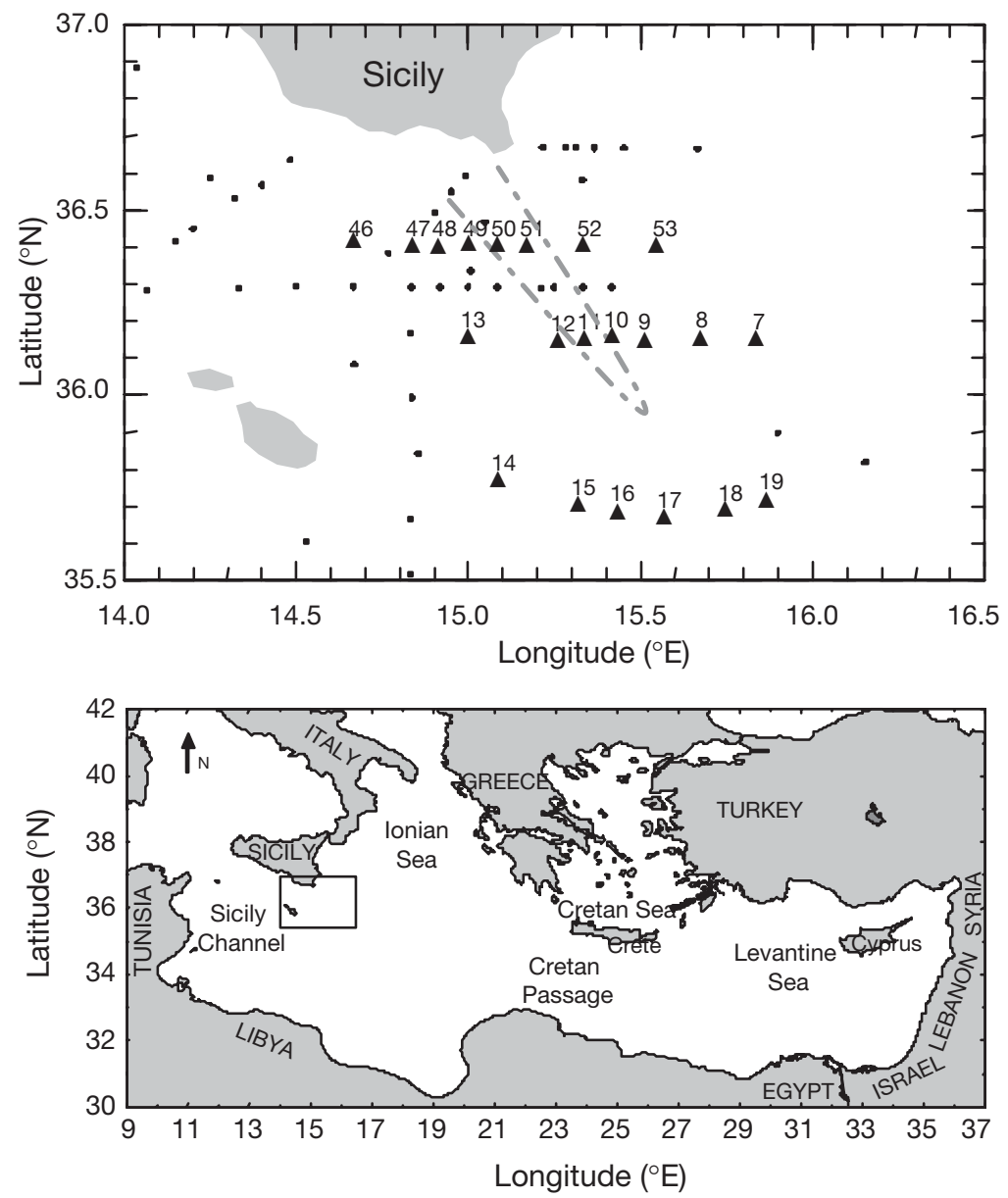

Fig. 1. Study area and sampling stations. The area delimited by the dashed lines indicates the surface filament location

cally, based upon different pigments used as taxonomic markers for the 2 size fractions (Casotti et al. 2000).

From pigment descriptors, the Shannon-Wiener diversity index $\left(H^{\prime}\right.$, Weithoff et al. 2001) was calculated as:

$$
H^{\prime}=\sum_{i=1}^{S} p_{i} \log _{2} p_{i}
$$

where $S$ is the number of classes and $p_{i}$ is the relative abundance of class $i\left(\sum p_{i}=1\right)$.

From $H^{\prime}$, Pielou's evenness index $J^{\prime}$ was calculated as:

$$
J^{\prime}=\frac{H^{\prime}}{H_{\max }}
$$

where $H_{\max }$ is the highest diversity estimated in all samples and is calculated as:

$$
H_{\text {max }}=\log _{2} i
$$

where $i$ is the number of descriptors used (Frontier 1985).

The value of $J^{\prime}$ falls entirely within the range from 0 to 1 , thus providing a scalefree measure of evenness. Both indices were calculated for the pigment descriptors separated by size class (6 descriptors for the $>3 \mu \mathrm{m}$ size fraction and 7 for the $<3 \mu \mathrm{m}$ size fraction) as well as for all descriptors pooled together (13 descriptors).

The Fp ratio, which relates the biomass of phytoplankton responsible for new production to total phytoplankton bio-

Pigments. For each sample, 31 of seawater were filtered onto Nuclepore filters of $3 \mu \mathrm{m}$ pore size and the filtrate onto Whatman GF/F filters. Filters were frozen and stored at $-40^{\circ} \mathrm{C}$ in the dark for a maximum of $2 \mathrm{wk}$ before analysis. Frozen filters were mechanically ground in $100 \%$ methanol and the extract injected into a Beckman System Gold HPLC following the procedure of Vidussi et al. (1996). A $3 \mu \mathrm{m} \mathrm{C}$ BDS column $(100 \times 4.6 \mathrm{~mm})$ was used and the mobile phase was composed of 2 solvent mixtures: (1) methanol/aqueous ammonium acetate, ratio 70/30, and (2) methanol. Absorbance was detected at $440 \mathrm{~nm}$ using a model 168 Beckman photodiode array detector. Fluorescence was measured using a Sfm 25 Kontron spectrofluorometer with excitation at $407 \mathrm{~nm}$ and emission at $660 \mathrm{~nm}$. Monospecific algal cultures and purified pigments from the Water Quality Institute, International Agency for ${ }^{14} \mathrm{C}$ Determination, were used as standards.

The contribution of each phytoplankton group to total phytoplankton biomass ( $\mathrm{chl}$ a) was obtained using group-specific conversion factors determined empiri- mass (Claustre 1994), was estimated as the ratio between fucoxanthin and peridinin and the sum of all chemotaxonomic biomarker pigments (fucoxanthin, 19'hexanoyloxyfucoxanthin, 19'butanoyloxyfucoxanthin, peridinin, alloxanthin, zeaxanthin and chl $b$ ).

Apart from taxonomic pigments generally involved in the photosynthetic process, we also identified and quantified 2 pigments involved in photoprotection: diatoxanthin (Dt) and diadinoxanthin (Dd). These are components of an epoxidation-de-epoxidation cycle present in brown algae, which is regulated by light (Brunet et al. 2003). The ratio of single pigments to chl a indicates what proportion of the pigment pool is devoted to protect cells from excess light, whereas the ratio of each pigment to the 2 pooled together (e.g. $\mathrm{Dt} /[\mathrm{Dt}+\mathrm{Dd}])$ is independent of chl a concentrations, and is therefore an indicator of the activation of the photoprotection process.

Dt and Dd, together with zeaxanthin and $\beta$-carotene (which may also act as a photoprotectant) are defined here as non-photosynthetic carotenoids (NPC), and 
their ratio to carotenoids involved in photosynthesis (photosynthetic carotenoids: PC) were previously used as an indicator of photoprotection at the community level (Lindley et al. 1995).

In order to investigate picoeukaryote photoacclimation, intracellular chl a concentrations of these algae were estimated by dividing the fraction of the $<3 \mu \mathrm{m}$ chl a attributable to picoeukaryotes by their cell numbers obtained by flow cytometry. In order to do so, we followed a 2-step procedure. Firstly, and considering zeaxanthin as a marker pigment of prokaryotes, we used a mean value of 0.77 for the ratio zeaxanthin/ divinyl-chlorophyll $a$, as reported by Partensky et al. (1993) in a culture study of photoacclimation of a Mediterranean strain of Prochlorococcus. In addition, we calculated the zeaxanthin contribution of Synechococcus by using a value of $1.8 \mathrm{fg}$ zeaxanthin per Synechococcus cell, following the study of Kana et al. (1988), who investigated photophysiology of Synechococcus under a wide range of light intensities. This allowed us to account for the zeaxanthin attributable to the 2 cyanobacteria. Secondly, we used a conversion factor of 0.5 for the zeaxanthin/chl a ratio, which allowed separation of Synechococcus from the picoeukaryote contribution to chl a. This approach is based upon a number of assumptions and represents an approximation. It is limited by the fact that it uses fixed values for the pigment ratios, which may vary with light conditions. However, the zeaxanthin/chl a ratio is not reported to vary considerably with changing light conditions (Kana et al. 1988, Moore et al. 1995). Therefore, although one must be cautious when attempting to extrapolate the properties of complex natural communities from single strains of organisms, we considered this to be the best approximation possible. In fact, values were drawn from studies encompassing a wide range of light conditions and from a strain of Prochlorococcus that originated from the oligotrophic Mediterranean Sea, which can be considered representative of populations present in the studied area.

Because the HPLC method used did not allow the separation of chl $b$ from divinyl-chlorophyl $b(\operatorname{dvchl} b)$, the chl $b$ content attributable to picoeukaryotes was assessed after eliminating the contribution of $\operatorname{dvchl} b$ from Prochlorococcus. We used values of 0.20 and $0.10 \mathrm{fg}$ dvchl $b$ per Prochlorococcus cell for low light (deep layer) and high light (surface layer) samples, respectively (values obtained from Partensky et al. 1993).

\section{RESULTS}

\section{Hydrology, nutrients and phytoplankton biomass}

Two different water masses, based on salinity differences in surface waters ( 0 to $50 \mathrm{~m}$ ), were present at the time of sampling. Atlantic Water (AW), with lower salinity, was situated west of $15.4^{\circ} \mathrm{E}$, and Ionian Water (IW), with higher salinity, was east of $15.4^{\circ} \mathrm{E}$ (Fig. 2a, Table 1). A haline front, located between Stns 50 and 10, separated these 2 water masses (Fig. 2c). Within the IW at the surface, the salinity and temperature isopleths curved, indicating the presence of a circular hydrological structure (Fig. 2a,b). A shallow (5 m) filament of colder, denser water was observed (Fig. 3a,b),

Table 1. Measured parameters in different water masses: Atlantic Water (AW), Ionian Water (IW), and front-filament (FF). Nutrient concentrations in $\mu \mathrm{M}$, biomass (chl $a+d v c h l a)$ in $\mu g ~^{-1}$; Surf: surface layer (0-50 m); DCM: deep chlorophyll maximum; S: salinity (psu); Pico \%: [100( $\left.\left.\operatorname{chl~} a_{<3}+\operatorname{dvchl} a\right) \times\left(\operatorname{chl~} a_{<3}+\text { dvchl } a+\operatorname{chl~} a_{>3}\right)^{-1}\right]$ ( $\operatorname{chl} a_{<3}$ : chl a concentration in $<3 \mu$ size fraction; chl $a_{>3}$ : chl $a$ concentration in $>3 \mu \mathrm{m}$ size fraction $) ;$ dvchl $a \%$ : $\left[100(\mathrm{dvchl} a) \times\left(\operatorname{chl} a_{<3}+\mathrm{dvchl} a\right)^{-1}\right] ; J^{\prime}:$ evenness index; Fp: ratio between fucoxanthin and peridinin and the sum of all chemotaxonomic biomarker pigments; NPC: non-photosynthetic carotenoids; PC: photosynthetic carotenoids; Pros, Syn and Picoeuk: cell concentrations (ml ${ }^{-1}$ ) of Prochlorococcus, Synechococcus and picoeukaryotes, respectively. SD in brackets

\begin{tabular}{|c|c|c|c|c|c|c|}
\hline & AW Surf & AW DCM & FF Surf & FF DCM & IW Surf & IW DCM \\
\hline $\mathrm{S}$ & 35.87 (4.18) & $36.28(3.86)$ & $37.46(0.10)$ & $38.04(0.20)$ & $38.08(0.26)$ & $38.27(0.21)$ \\
\hline $\mathrm{NO}_{3}$ & $0.07(0.08)$ & $1.22(1.51)$ & $1.25(2.01)$ & $3.22(3.08)$ & $0.12(0.06)$ & $2.12(1.02)$ \\
\hline $\mathrm{PO}_{4}$ & $0.09(0.04)$ & $0.21(0.13)$ & $0.49(0.52)$ & $0.28(0.24)$ & $0.12(0.03)$ & $0.21(0.08)$ \\
\hline $\mathrm{SiO}_{4}$ & $0.95(0.16)$ & $1.86(1.24)$ & $3.50(3.45)$ & $2.73(2.20)$ & $1.10(0.16)$ & $2.20(0.74)$ \\
\hline Biomass & $0.036(0.010)$ & $0.131(0.072)$ & $0.054(0.020)$ & $0.302(0.081)$ & $0.047(0.022)$ & $0.193(0.104)$ \\
\hline Pico \% & 70.20 (9.40) & 89.73 (8.76) & 73.24 (8.77) & 72.77 (10.60) & $76.02(15.00)$ & $83.70(11.20)$ \\
\hline Dvchl a \% & $34.40(8.40)$ & $43.90(8.80)$ & $50.81(19.20)$ & $29.10(10.02)$ & $19.30(12.50)$ & 32.33 (13.20) \\
\hline$J^{\prime}$ & $0.31(0.10)$ & $0.53(0.13)$ & $0.39(0.08)$ & $0.60(0.12)$ & $0.53(0.19)$ & $0.59(0.10)$ \\
\hline Fp & $0.062(0.030)$ & $0.210(0.080)$ & $0.235(0.100)$ & $0.245(0.07)$ & $0.160(0.09)$ & $0.310(0.110)$ \\
\hline NPC/PC ratio & $4.75(1.30)$ & 1.19 (0.80) & $2.59(1.00)$ & $0.45(0.15)$ & $2.00(1.20)$ & $0.55(0.40)$ \\
\hline Pros & 33238 (21005) & $118912(54112)$ & 62058 (27954) & $65810(43250)$ & 15557 (5557) & 69777 (33637) \\
\hline Syn & $11374(5500)$ & $3160(1450)$ & $10220(3950)$ & 2456 (1020) & $9028(4250)$ & $5969(4200)$ \\
\hline Picoeuk & 754 (226) & 656 (295) & 1067 (583) & 580 (428) & 725 (160) & 379 (215) \\
\hline
\end{tabular}



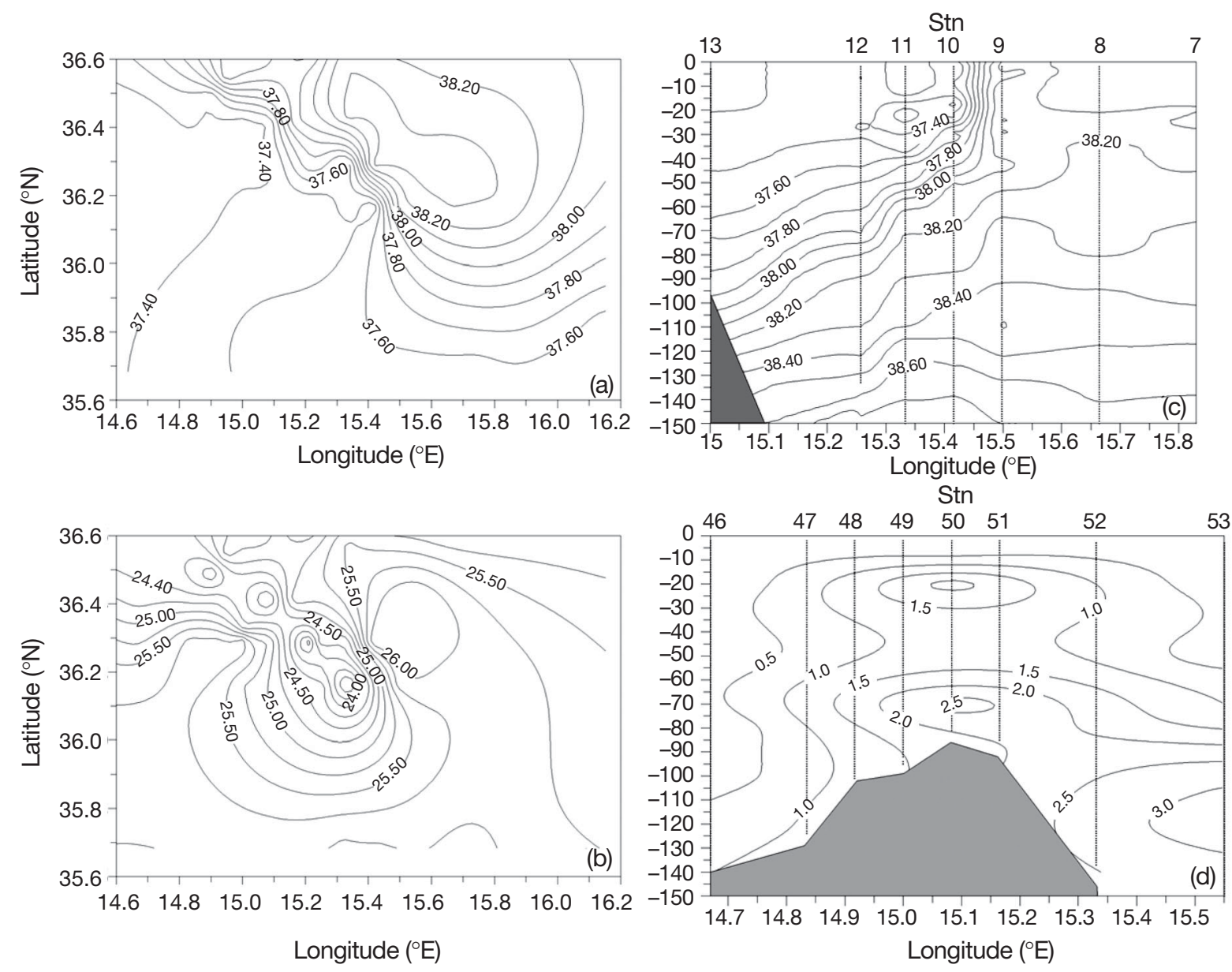

Fig. 2. Contour plots of surface $(5 \mathrm{~m})(\mathrm{a})$ salinity (psu) and (b) temperature $\left({ }^{\circ} \mathrm{C}\right)$, and vertical distribution of $(\mathrm{c})$ temperature $\left({ }^{\circ} \mathrm{C}\right)$ and $(\mathrm{d})$ nitrate concentration $(\mu \mathrm{M})$

corresponding to the front and separating the 2 water masses (between Stns 50 and 11), and extending up to $35.8^{\circ} \mathrm{N}$ (Fig. 3c). The filament location was clearly marked by a drop in temperature $\left(<24^{\circ} \mathrm{C}\right)$, and it originated from the wind-induced upwelling of deep waters along the southern coast of Sicily and is a recurrent feature of this area (Bohm et al. 1998, Béranger et al. 2004 and references therein).

Below the thermocline, a gradual increase in salinity and decrease in temperature were observed, with values typical of the IW. This was more noticeable at the eastern stations, and gradually merged into the Levantine Intermediate Water (LIW) from $120 \mathrm{~m}$ downwards (Fig. 3a,b). At the most southerly stations, profiles of salinity (not shown) and temperature (Fig. 3c) demonstrated the water column to be well stratified between Stns 14 and 19.

Concentrations of nitrate, phosphate and silicate ranged from 0.002 to $7.50 \mu \mathrm{M}, 0.052$ to $1.86 \mu \mathrm{M}$ and 0.69 to $12.07 \mu \mathrm{M}$, respectively, and increased with depth. Higher concentrations of nutrients were found in higher salinity and colder (deep) waters, as confirmed by the significant correlation with temperature, density and salinity ( $p<0.001$ for all correlations). With respect to surrounding stations, significantly higher nitrate (Fig. 2d) and silicate (not shown) concentrations were measured in the filament and in the front at the surface (Table 1).

Chlorophyll concentrations ranged between 0.010 and $0.60 \mu \mathrm{g} \mathrm{chl} \mathrm{al}^{-1}$, with a deep chlorophyll maximum (DCM) always present between 50 and $80 \mathrm{~m}$ depth (Fig. 4). The $<3 \mu \mathrm{m}$ (picophytoplankton) size fraction dominated numbers and biomass at all stations, accounting for an average of $80 \%( \pm 10 \% \mathrm{SD})$ of total chl a. Total chl a concentrations were directly correlated with all nutrients $(\mathrm{p}<0.01)$ and to hydrological parameters (temperature, salinity and density, p < $0.01)$. The larger size fraction $(>3 \mu \mathrm{m})$ showed a stronger direct correlation with nutrients and salinity $(p<0.001)$ than smaller phytoplankton $(p<0.01)$, corresponding to its relatively higher contribution to the DCM in comparison to the surface. 

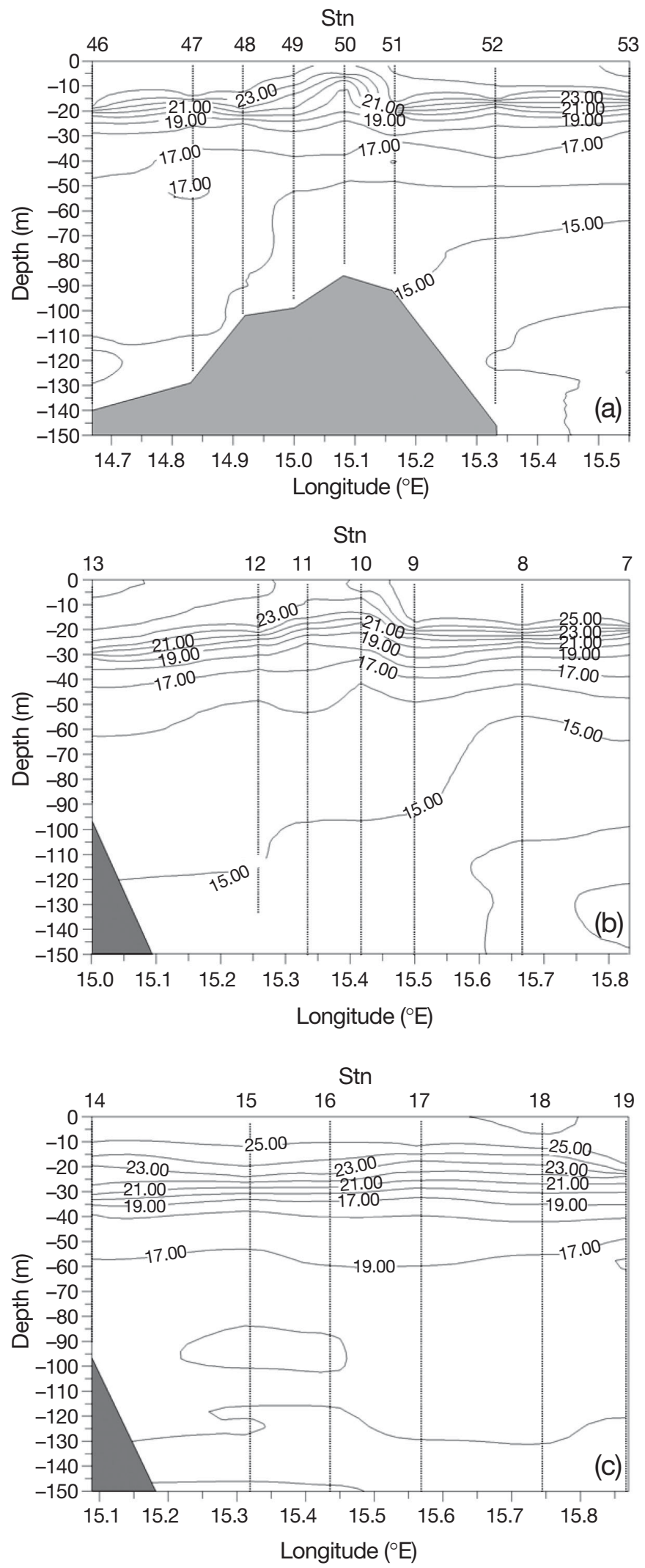

Fig. 3. Vertical distribution of temperature $\left({ }^{\circ} \mathrm{C}\right)$ along 3 transects: (a) Stns 46 to 53, (b) Stns 13 to 7 and (c) Stns 14 to 19 (see Fig. 1)

\section{Phytoplankton pigments}

The relative contribution (\%) of different taxonomic groups to total chl a biomass was estimated from phytoplankton marker pigments analyzed by HPLC and attributed to different taxonomic groups using conversion factors (Casotti et al. 2000, 2003). Results are presented in Fig. 5. At the surface, zeaxanthin was the dominant biomarker pigment, accounting on average for $75 \%( \pm 7 \% \mathrm{SD})$ of total biomass and indicating that cyanobacteria were dominant. Percent contribution of zeaxanthin was higher in the AW $(75.5 \pm 17.0 \%$ $\mathrm{SD})$ than in the IW $(50.8 \pm 18.0 \% \mathrm{SD})$. The 19 'butanoyloxyfucoxanthin (19'BF, marker of pelagophytes) and 19 'hexanoyloxyfucoxanthin $\left(19^{\prime} \mathrm{HF}\right.$, marker of prymnesiophytes) represented the 2 major eukaryotepigments in both size fractions, increasingly dominating the lower size class $(<3 \mu \mathrm{m})$ in an eastward direction (Fig. 5, surface layer). Peridinin (dinophytes) and alloxanthin (cryptophytes) contributed very little to total biomass in either size fractions.

The dvchl a, marker of Prochlorococcus, was inversely correlated with temperature $(p<0.001)$ as a consequence of its higher abundance in colder and/or deeper waters. All pigment/chl a ratios in the $<3 \mu \mathrm{m}$ size fraction were directly correlated with salinity $(\mathrm{p}<$ 0.05 ), with the exceptions of prasinoxanthin (marker of some prasinophytes; Zingone et al. 2002) and zeaxanthin (marker of prokaryotes and also of photoprotection in green algae), which were inversely correlated with salinity $(\mathrm{p}<0.001)$. This indicated their association with the surface layer. In the $>3 \mu \mathrm{m}$ size fraction, only the $19^{\prime} \mathrm{HF} / \mathrm{chl}$ a ratio was significantly (and negatively) correlated with salinity $(\mathrm{p}<0.01)$.

At all stations, the contribution of zeaxanthin to total chl $a$ in the DCM was lower than at the surface, whereas the contribution of $19^{\prime} \mathrm{BF}$ in the $<3 \mu \mathrm{m}$ size fraction increased (Fig. 5). Virtually all eukaryotic marker pigments were observed, with $19^{\prime} \mathrm{BF}$ (pelagophytes) being dominant (Fig. 5). Only peridinin (dinophytes) was absent, and alloxanthin (cryptophytes) was present in traces $(0.5 \%)$. The $>3 \mu \mathrm{m}$ size class was poorly represented in the DCM and was dominated by $19^{\prime} \mathrm{BF}$ (pelagophytes) and 19'HF (prymnesiophytes).

In the smaller size fraction (picophytoplankton), all known chemotaxonomic pigments were present and contributed strongly to the picophytoplankton pigment pool (Table 2), including diatoms and dinophytes, which are usually considered to contribute almost exclusively to the nano- and microplankton (e.g. Vidussi et al. 2001).

The ratio of each pigment in the $<3 \mu \mathrm{m}$ size class and the sum of its concentration in the 2 size classes was used as an index of size-dependent community composition (Table 2). In general, all pigments contributed 
AW

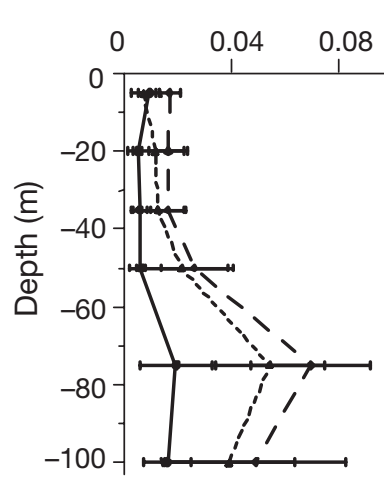

FF

Chl a or dvchl a concentration ( $\left.\mu \mathrm{g} \mathrm{l}^{-1}\right)$

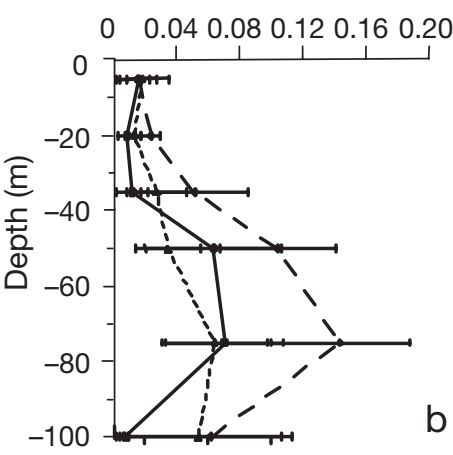

IW

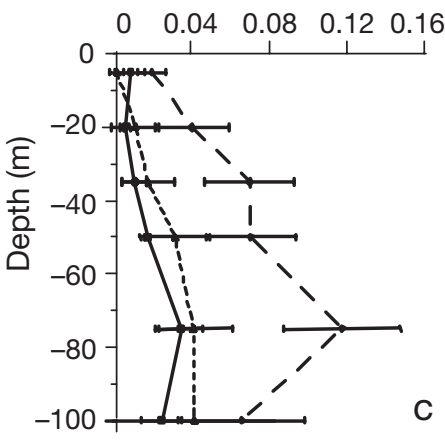

Fig. 4. Vertical profiles of average concentrations of chl $a$ in $<3 \mu \mathrm{m}$ size fraction (long dashed line), chl $a_{>3}$ (solid line) and dvchl $a$ (short dashed line) in (a) Atlantic Water $(\mathrm{AW} ; \mathrm{n}=5)$, (b) front-filament $\left(\mathrm{FF}_{;} \mathrm{n}=3\right.$ ) and (c) Ionian Water $(\mathrm{IW} ; \mathrm{n}=6)$. Error bars $= \pm \mathrm{SD}$

most to the $<3 \mu \mathrm{m}$ size class, with different relative contributions between the surface and the DCM. Two exceptions were observed: fucoxanthin (diatoms) and alloxanthin (Cryptophytes) in surface waters contributed more to the $>3 \mu \mathrm{m}$ fraction (Table 2).

In order to better represent the diversity within the phytoplankton community, we used Pielous' evenness index $\left(J^{\prime}\right)$ calculated from pigment data (see 'Materials and methods'), whose value is directly proportional to diversity in terms of number of taxonomic groups. $J^{\prime}$ was higher in the DCM than in the surface layer ( $\mathrm{p}<$ 0.001 , Table 1), reflecting the higher pigment diversity in this water layer with respect to the surface, where prokaryotes largely dominated. Significant differences
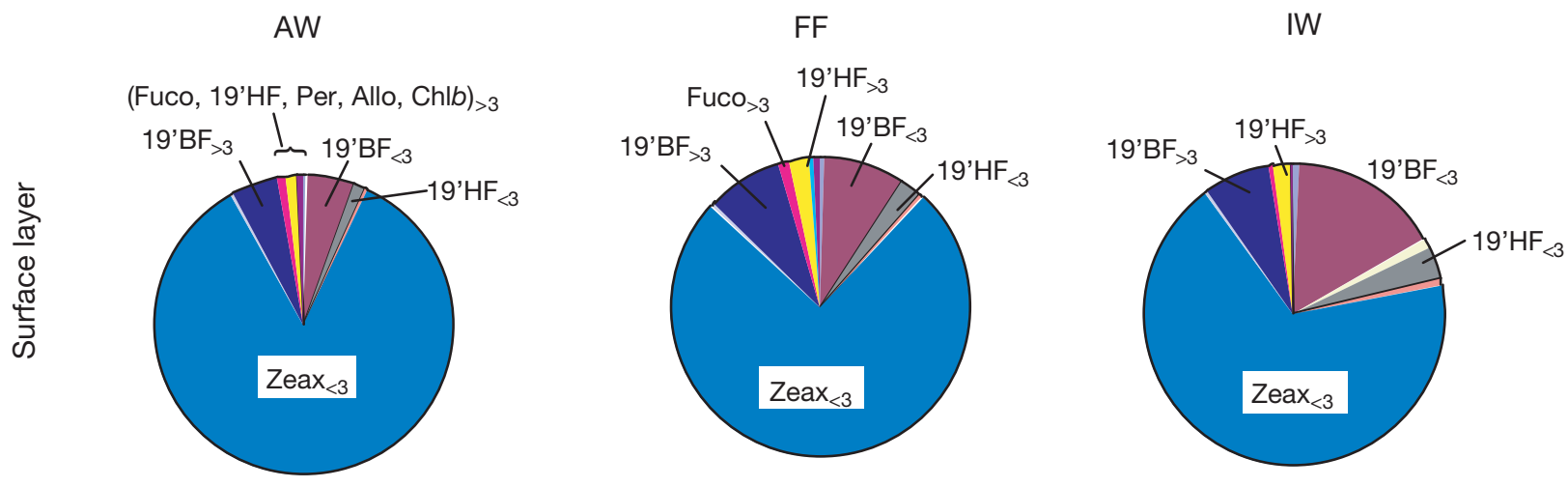

(Fuco, 19'HF, Per, Allo, Chlb) $>3$
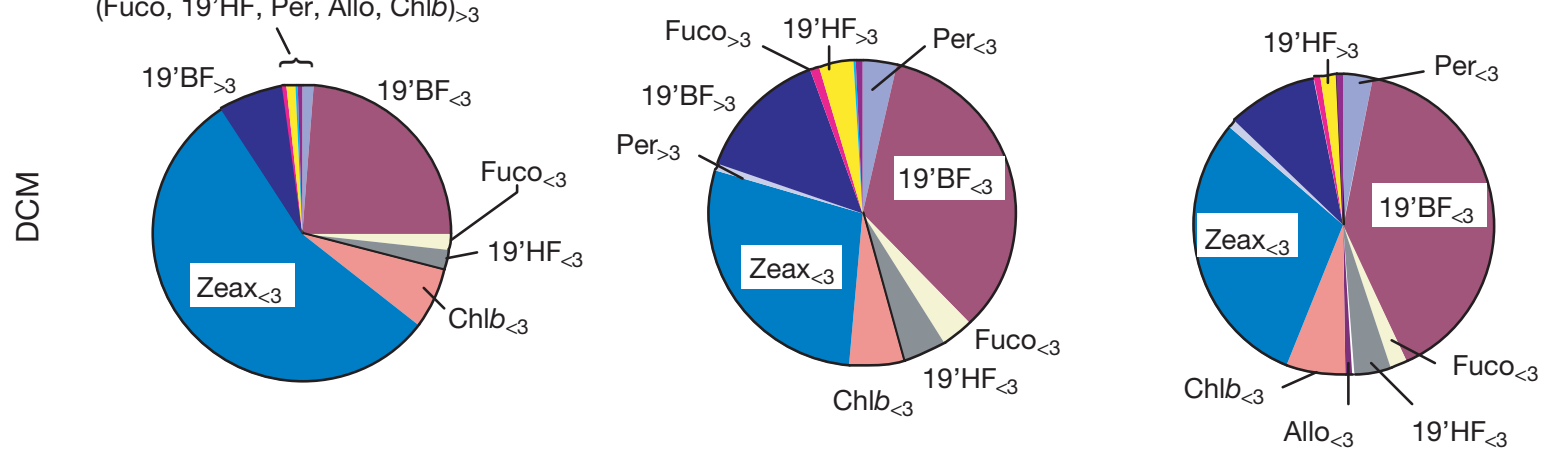

Fig. 5. Percent contribution of different chemotaxonomic pigments to total chl $a$ in the surface layer $(0-50 \mathrm{~m})$ and DCM (50-80 m) of the AW, FF and IW. $<3:<3 \mu \mathrm{m}$ size fraction, $>3:>3 \mu \mathrm{m}$ size fraction; Allo: alloxanthin; chl $b$ : chlorophyll $b+$ divinyl-chlorophyll b; Fuco: fucoxanthin; 19'BF: 19'butanoyloxyfucoxanthin; 19'HF: 19'hexanoyloxyfucoxanthin; Per: peridinin; Zeax: zeaxanthin 
Table 2. Ratios of each pigment in the $<3 \mu \mathrm{m}$ size fraction to sum of its concentration in the 2 size fractions $\left[X_{<3}\left(X_{<3}+\right.\right.$ $\left.X_{>3}\right)^{-1}$, where $X_{<3}$ and $X_{>3}$ are pigment concentrations $\left(\mu \mathrm{g} \mathrm{l}^{-1}\right)$ in $<3$ and $>3 \mu \mathrm{m}$ size fractions, respectively]. Data are means (SD). p: significance level of comparison between the surface and DCM (Student $t$-test); ns: not significant; Per: peridinin (dinophytes); 19'BF: 19'butanoyloxyfucoxanthin (pelagophytes); Fuco: fucoxanthin; 19'HF: 19'hexanoyloxyfucoxanthin (prymnesiophytes); Allox: alloxanthin (cryptophytes); Zeax: zeaxanthin (prokaryotes); chl $b$ : chlorophyll $b$ (green algae); chl $c_{3}$ : chlorophyll $c_{3}$ (prymnesiophytes); Pras: prasinoxanthin (some prasinophytes)

\begin{tabular}{|c|c|c|c|c|}
\hline & All water masses & DCM & Surface & $\mathrm{p}$ \\
\hline Per & $0.73(0.26)$ & $0.78(0.26)$ & $0.66(0.31)$ & 0.003 \\
\hline $19^{\prime} \mathrm{BF}$ & $0.70(0.21)$ & $0.74(0.16)$ & $0.63(0.16)$ & 0.002 \\
\hline Fuco & $0.57(0.40)$ & $0.75(0.29)$ & $0.32(0.41)$ & 0.001 \\
\hline $19^{\prime} \mathrm{HF}$ & $0.57(0.26)$ & $0.67(0.23)$ & $0.51(0.20)$ & 0.02 \\
\hline Allox & $0.54(0.48)$ & $0.63(0.45)$ & $0.27(0.44)$ & 0.002 \\
\hline Zeax & $0.93(0.23)$ & $0.95(0.16)$ & $0.93(0.16)$ & $\mathrm{ns}$ \\
\hline Chl $b$ & $0.80(0.25)$ & $0.90(0.11)$ & $0.71(0.28)$ & 0.001 \\
\hline $\mathrm{Chl} c_{3}$ & $0.66(0.30)$ & $0.68(0.26)$ & $0.66(0.31)$ & ns \\
\hline Pras & $0.97(0.14)$ & $0.97(0.19)$ & $0.99(0.01)$ & ns \\
\hline
\end{tabular}

in $J^{\prime}$ were measured between the surface layers of the different water masses, with higher values in the IW (Table 1). No significant differences were observed between the different DCMs. $J$ ' was significantly correlated to temperature and $\mathrm{chl} a(\mathrm{p}<0.001$, Fig. 6), except for temperature at $5 \mathrm{~m}$ depth in the IW $(\boldsymbol{\Delta}$, Fig. 6a). $J^{\prime}$ was also significantly higher for the larger size fraction $(0.58 \pm 0.11 \mathrm{SD})$ when compared to the $<3 \mu \mathrm{m}$ fraction $(0.48 \pm 0.21 \mathrm{SD})$, and values had a smaller range ( 0.30 to 0.77 vs. 0.13 to 0.77$)$.

Fp values, representing the proportion of phytoplankton responsible for new production, ranged
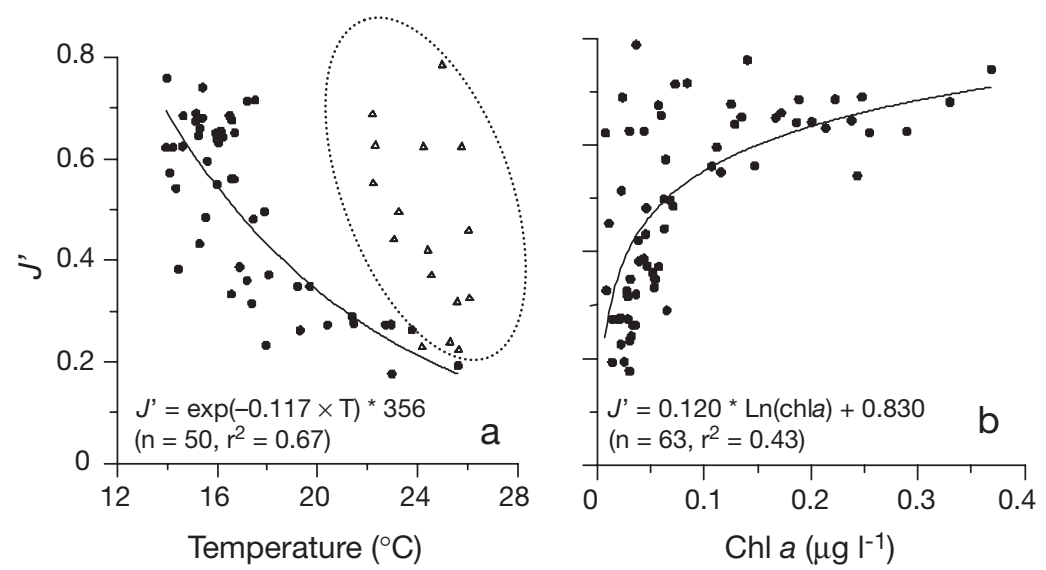

Fig. 6. Correlations between Pielou's evenness index $J^{\prime}$ and (a) temperature $\left(T_{i}{ }^{\circ} \mathrm{C}\right)$ and $(\mathrm{b}) \mathrm{chl} \mathrm{a}\left(\mu \mathrm{g} \mathrm{l}^{-1}\right)$. $\mathbf{\Delta}$ : data from $5 \mathrm{~m}$ depth in IW, which were not considered for the correlation (see text). Lines represent non-linear fit described by inset equations between 0.03 and $0.40(0.22 \pm 0.11 \mathrm{SD}$, Table 1), reflecting the dominance of algal groups utilizing regenerated forms of nitrogen to fuel their primary production. Average total values were similar for the 2 size classes $(0.21$ and 0.25 for $<3$ and $>3 \mu \mathrm{m}$, respectively), owing to only a minor contribution from diatoms and dinophytes. Fp was significantly ( $p<0.001)$ correlated to hydrological parameters, nutrient and chl a concentrations, in agreement with its higher values in colder and richer waters. Although values of Fp in the different DCMs were very similar, significantly higher values $(p<0.01)$ were observed in the frontfilament (FF) area at the surface, mainly owing to the greater presence of diatoms in this water mass (fucoxanthin was 3 times more concentrated in this area than in the AW, and 10 times more than in the IW) and to higher nutrient concentrations.

\section{Photoprotection markers}

Estimation of the degree of photoprotection of the phytoplankton community at the time of sampling reflects the light history of the algae, and provides an indication of their movement through the water column. Dt and Dd contributed more to total biomass in terms of chl $a$ at the surface than at depth, due to their role as photoprotectant pigments (Fig. $7 \mathrm{a}-\mathrm{c}$ ). When considering the ratio $\mathrm{Dt} /(\mathrm{Dt}+\mathrm{Dd}$ ) (which is independent of the total biomass present), it was noted that, despite a general decreasing trend with depth (Fig. 7d-f), values stayed constant in the first $50 \mathrm{~m}$ of the AW (Fig. 7d), indicating elevated mixing rates in this water mass. This was further reinforced by the homogeneous distribution of chl a (Fig. 4a). Values also increased below $50 \mathrm{~m}$ at all stations, probably as a consequence of physiological stress (e.g. Brunet et al. 1992) or prolonged darkness (Jakob et al. 2001).

When considering photoprotection at the community level, the high degree of photoprotection at the surface was confirmed by the high values of ratios NPC/PC (Table 1) and NPC/chl a (data not shown). Both ratios were directly correlated with temperature $(p<0.001)$, and NPC/PC was also significantly correlated with salinity, total biomass and Fp (Table 3). Correlations between photoprotective indicators and physical or biological parameters provided numerical equations (Table 3), which could be useful for bio-optical characterization of the area. 

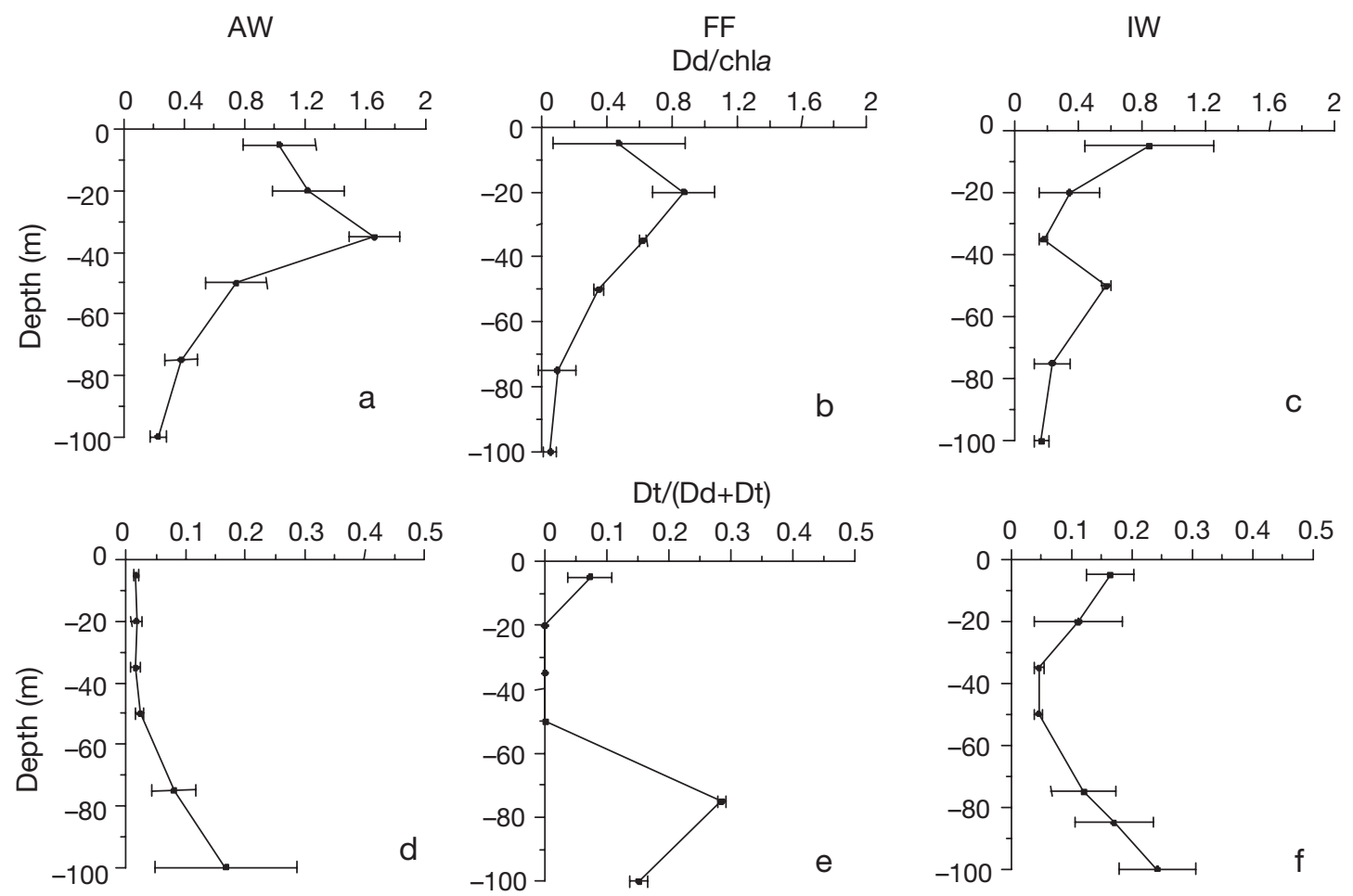

$\mathrm{Dt} /(\mathrm{Dd}+\mathrm{Dt})$

Fig. 7. Mean vertical profiles of $(\mathrm{a}-\mathrm{c}) \mathrm{Dd} / \mathrm{chl}$ a ratios and $(\mathrm{d}-\mathrm{f}) \mathrm{Dt} /(\mathrm{Dt}+\mathrm{Dd})$ ratios in the AW, FF and IW

\section{Picophytoplankton: diversity and pigment content}

As detected by flow cytometry, picophytoplankton was numerically dominated by Prochlorococcus, with average concentrations of $5.2 \times 10^{4}$ cells ml $\mathrm{m}^{-1}( \pm 5.1 \times$ $10^{4}$ cells ml $\left.{ }^{-1} \mathrm{SD}\right)$. Synechococcus accounted for $5.8 \times$ $10^{3}$ cells ml ${ }^{-1}\left( \pm 5.8 \times 10^{3}\right.$ cells $\left.\mathrm{ml}^{-1} \mathrm{SD}\right)$, whereas picoeukaryotes accounted for $0.6 \times 10^{3}$ cells ml $^{-1}( \pm 0.4 \times$ $10^{3}$ cells ml ${ }^{-1}$ SD). Prochlorococcus was more concentrated in the DCM of the AW, whereas Synechococcus was more concentrated at the surface and in the IW slightly above the DCM (Fig. 8). In general, picoeukaryotes were more abundant at the surface than in the DCM, whereas Prochlorococcus was very abundant at the surface in the AW and in the FF (Table 1). Prochlorococcus had higher red autofluorescence and dvchl a cell ${ }^{-1}$ in the FF (Fig. 9e) in comparison with surrounding stations sampled at the same time of day. This supports the notion of the generation of the filament from deep (and darker) waters as a result of coastal upwelling and wind advection.

All picophytoplankton showed an increase in cellular red fluorescence with depth (Fig. 9a-c), which is related to strong photoacclimation (particularly evident in Prochlorococcus and picoeukaryotes). Photoacclimation was also apparent from the increase in estimated chl a (fg cell ${ }^{-1}$ ) with depth at all stations (Fig. 9d-f).
Prochlorococcus had an average dvchl a content of $0.44 \mathrm{fg} \mathrm{cell}^{-1}( \pm 0.62 \mathrm{SD})$ above $50 \mathrm{~m}$ depth, and $1.56 \mathrm{fg}$ cell $^{-1}( \pm 0.54 \mathrm{SD})$ below $50 \mathrm{~m}$, the 2 values being significantly different $(p<0.01)$. This was probably due to phoadaptation rather than to photoacclimation, as evidenced by the presence of 2 ecotypes of Prochlorococcus in the water column-one replacing the other

Table 3. Equations representing non-linear correlations between hydrological, biological and physiological parameters. For each correlation, $\mathrm{n}=60$. $T$ : temperature; Fp: ratio between fucoxanthin and peridinin and the sum of all chemotaxonomic biomarker pigments; NPC: non-photosynthetic carotenoids; PC: photosynthetic carotenoids; S: salinity

\begin{tabular}{|c|c|c|}
\hline Parameters & Eq. & $\mathrm{r}^{2}$ \\
\hline Chl $a$ vs. $T$ & $\begin{array}{c}\ln (\operatorname{chl} a)= \\
-3.41 \times \ln T+7.004\end{array}$ & 0.61 \\
\hline$T$ vs. Fp & $\begin{array}{c}T= \\
-4.14 \times \ln (\mathrm{Fp})+11.62\end{array}$ & 0.45 \\
\hline Fp vs. chl a & $\begin{array}{c}\ln (\mathrm{Fp})= \\
0.51 \times \ln (\mathrm{chl} a)-0.514\end{array}$ & 0.54 \\
\hline $\begin{array}{l}\text { Fp vs. } \\
\text { NPC/PC ratio }\end{array}$ & $\begin{array}{c}\text { NPC/PC ratio }= \\
-2.188 \times \ln (\mathrm{Fp})-1.68\end{array}$ & 0.57 \\
\hline $\begin{array}{l}\text { NPC/PC ratio } \\
\text { vs. S }\end{array}$ & $\begin{array}{c}\ln (\mathrm{NPC} / \mathrm{PC} \text { ratio })= \\
-2.48 \mathrm{~S}+93.95\end{array}$ & 0.60 \\
\hline $\begin{array}{l}\text { NPC/PC ratio vs. } \\
\text { chl } a\end{array}$ & $\begin{array}{c}\text { NPC/PC ratio }= \\
0.127 \times(\mathrm{chl} a)^{-0.788}\end{array}$ & 0.33 \\
\hline
\end{tabular}




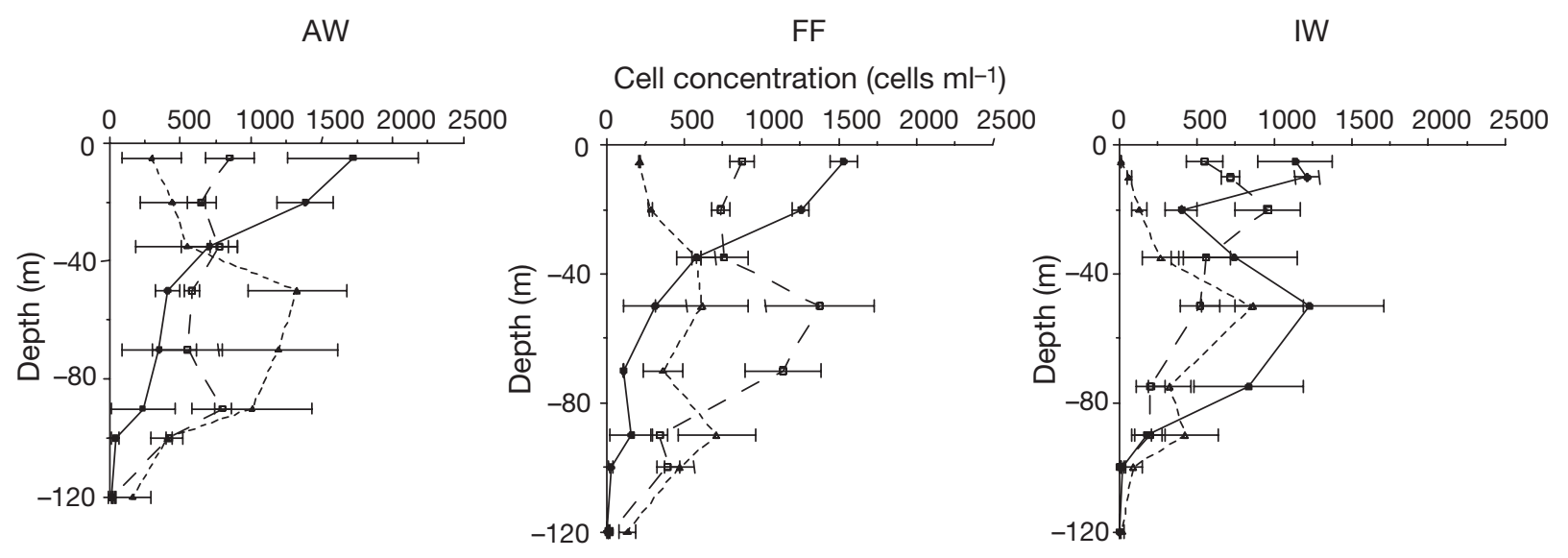

Fig. 8. Vertical profiles of cell concentrations of Synechococcus $\left(0.1 \times\right.$ cells ml $^{-1}$, solid line $)$, Prochlorococcus $\left(0.01 \times \mathrm{cells}^{-1}\right.$, dotted line) and picoeukaryotes (cells ml-1, dashed line) in (a) AW, (b) FF and (c) IW

between 50 and $80 \mathrm{~m}$ depth, as revealed by bimodal distributions of red fluorescence (not shown). Interestingly, Prochlorococcus in the filament followed the same relationship as the deep Prochlorococcus, and was much more fluorescent than at nearby stations sampled at the same time of day, therefore confirming the origin of the filament from upwelling of deep waters (Fig. 9e).

Mean chl a (fg cell ${ }^{-1}$ ) of picoeukaryotes was highly variable among the different water masses (Fig. 9d-f), with significantly higher $(\mathrm{p}<0.005)$ values in the DCM layers than at the surface, as a result of photoacclimation to decreased light irradiances. Differences were also found among the DCMs, with significantly higher values in the IW and in the FF water mass in comparison to the AW ( $p<0.005)$; in contrast, no differences were found among the different surface water masses $(\mathrm{p}>0.05)$.

Two different equations were also able to describe the relationship between chl $b$ concentration and picoeukaryote cell numbers. The chl $b$ content in picoeukayotes was estimated to be 21.9 and $47.4 \mathrm{fg} \mathrm{cell}^{-1}$ above and below $70 \mathrm{~m}$, respectively. This reflected the marked photoacclimative processes, with twice as much chl a per cell in the deeper layer with respect to the surface. It should be noted that values were obtained after extracting contributions of dvchl $b$, which were based upon known values reported by Partensky et al. (1993; described in 'Materials and methods'). However, we cannot exclude an additional contribution to chl $b$ by Prochlorococcus (Karl et al. 2001), even though chl $b$ was not detected in the Mediterranean Sea strain of Prochlorococcus analyzed by Partensky et al. (1993).

The equations relating chl a (or dvchl a) red fluorescence and cellular chl a (or dvchl a) content of Pro- chlorococcus and picoeukaryotes in the different systems are reported in Table 4 . The high significance of these relationships supports the validity of the approach used to calculate the pigment content of picoeukaryote cells, even though it was based on an assumption of the contribution of Synechococcus to zeaxanthin (see 'Materials and methods'). When all data were pooled together, the decrease in significance of the correlations reflected the heterogeneity of picophytoplankton responses to ecosystem properties, and was probably also driven by taxonomic segregation. This prevented the use of a single equation to relate the 2 cellular properties, and highlights the importance of mesoscale dynamics when considering physiological properties of phytoplankton.

Table 4. Linear correlations between chl a (or dvchl a) red fluorescence from flow cytometry (relative units) and cellular chl a (or dvchl a) content (fg cell ${ }^{-1}$ ) of picoeukaryotes and Prochlorococcus in 3 water masses (AW, FF and IW). Total: all data pooled together. Synecochoccus was excluded from analyses because its chl a content was drawn from published values (see 'Materials and methods')

\begin{tabular}{|ccc|}
\hline & Picoeukaryotes & Prochlorococcus \\
\hline Total & Red $=0.031 \mathrm{chl} a+6.43$ & Red $=0.73 \mathrm{dvchl} a-0.23$ \\
& $\mathrm{r}^{2}=0.30(\mathrm{n}=78)$ & $\mathrm{r}^{2}=0.55(\mathrm{n}=74)$ \\
AW & Red $=0.049 \mathrm{chl} a+5.09$ & $\mathrm{Red}=0.79 \mathrm{dvchl} a-0.23$ \\
& $\mathrm{r}^{2}=0.75(\mathrm{n}=30)$ & $\mathrm{r}^{2}=0.93(\mathrm{n}=28)$ \\
FF & Red $=0.081 \mathrm{chl} a+5.31$ & $\mathrm{Red}=1.46 \mathrm{dvchl} a-0.84$ \\
& $\mathrm{r}^{2}=0.77(\mathrm{n}=18)$ & $\mathrm{r}^{2}=0.86(\mathrm{n}=17)$ \\
IW & Red $=0.033 \mathrm{chl} a+5.08$ & $\mathrm{Red}=0.94 \mathrm{dvchl} a-0.38$ \\
& $\mathrm{r}^{2}=0.81(\mathrm{n}=30)$ & $\mathrm{r}^{2}=0.98(\mathrm{n}=29)$ \\
& &
\end{tabular}




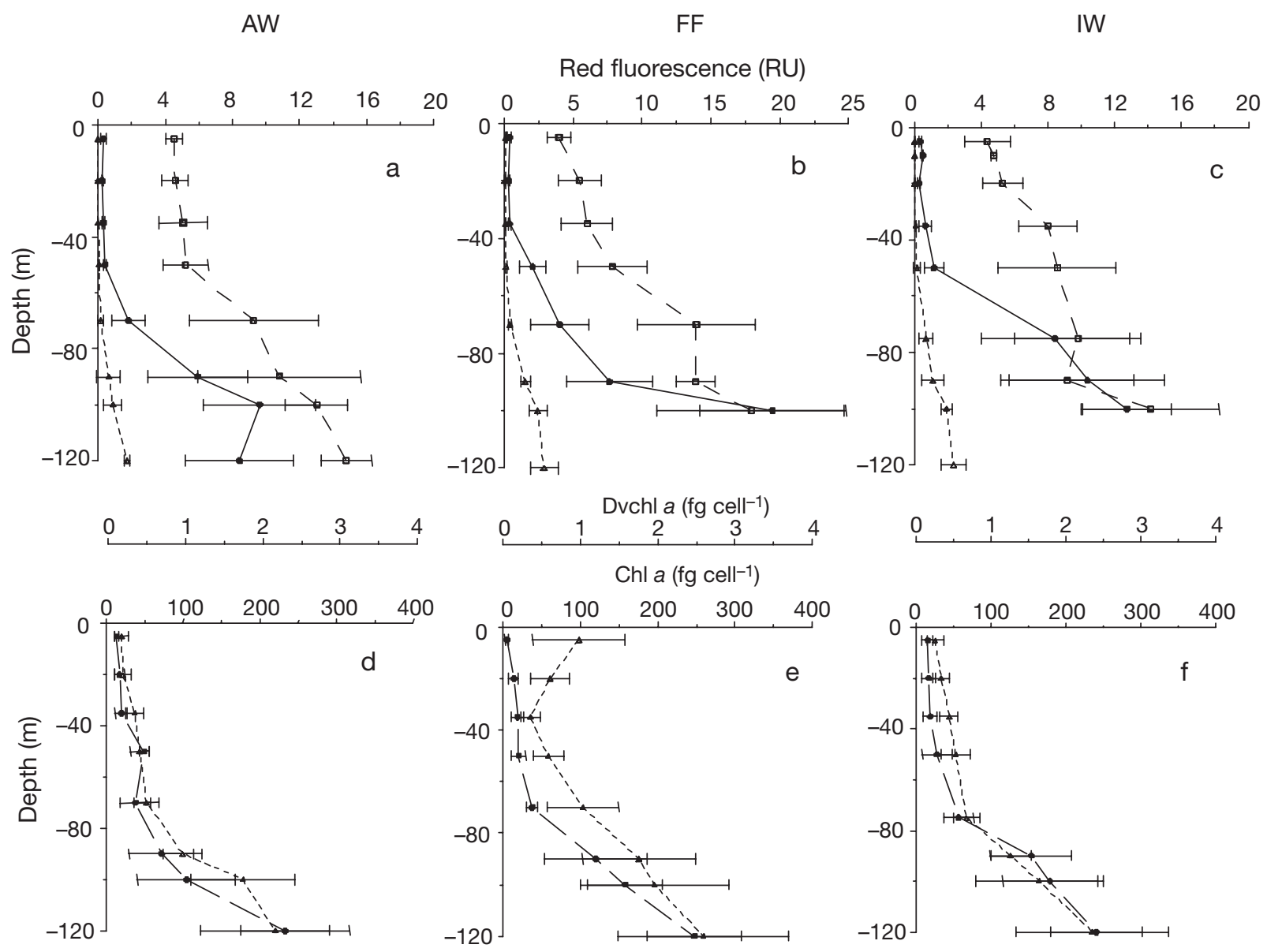

Fig. 9. Vertical profiles of red fluorescence of Synechococcus (solid line), Prochlorococcus (short dashed line) and picoeukaryotes (long dashed line) in (a) AW, (b) FF and (c) IW, and vertical profiles of dvchl a or chl a cell ${ }^{-1}$ for Prochlorococcus (short dashed line) and picoeukaryotes (long dashed line) in (d) AW (e) FF and (f) IW. RU: relative units

\section{DISCUSSION}

\section{Water mass distribution and properties}

The AW and IW were identified by their core salinity values, which lay within the ranges identified by other authors for these water bodies in the same area (Lermusiaux \& Robinson 2001, Béranger et al. 2004).

The distribution of isohalines curved in the IW (Fig. 2), indicating a circulating structure, marked also by relatively higher surface nutrient and chl a concentrations (Table 1). Mean values of photoprotective parameters within this structure (such as that of the NPC/PC ratio) indicated shade adaptation by surface phytoplankton, and all these properties converged to suggest a relatively deeper origin of the algal community and, therefore, a cyclonic direction of the rotating structure. We classified this water body as the Ionian Shelf Break Vortex, reported by other authors as a recurrent feature of the Strait of Sicily in summer, which originates from the eastward flow of the AW combined with bottom irregularities and related upwelling along the southern coast of Sicily (Lermusiaux \& Robinson 2001, Béranger et al. 2004).

The hydrological boundaries of the vortex were not very strong at the time of sampling, indicating that the structure was only at the beginning of its generation, in accordance with reports from other authors who have reported its presence for the month of August (Lermusiaux \& Robinson 2001, Béranger et al. 2004). However, biological parameters clearly indicated different properties of the phytoplankton community within the vortex, suggesting its separation from other water masses. For example, phytoplankton community composition varied with respect to that of other waters, with a higher contribution of picoeukaryotes, in particular pelagophytes and prymnesiophytes, which were also observed to thrive in similar cyclonic eddies elsewhere (Olaizola et al. 1993, Vaillancourt et al. 2003). The decrease in Prochlorococcus inside the vortex 
agreed with observations of Vaillancourt et al. (2003) for a cyclonic eddy in the subtropical Pacific Ocean, and was probably due to relatively higher nitrate concentrations, which confer a competitive advantage to Synechococcus and picoeukaryotes (Moore et al. 2002). The lack of differentation in phytoplankton diversity between the surface and DCM in the IW (Table 1) might have provided early evidence of the vortex, which may have helped to maintain high diversity by providing perturbation. This perturbation was probably responsible for the lack of a significant relationship between $J^{\prime}$ and temperature at $5 \mathrm{~m}$ (Fig. 6a), because it increased the variability and dispersion of the diversity at scales smaller than the mesoscale.

Lowest values of Fp and $J^{\prime}$ were observed within the AW, coincident with low nutrient concentrations. This supports the hypothesis of Huisman \& Weissing (1999, and references therein), who stated that the limitation of 1 ecological resource (in our case, nutrients) induces a decrease in the diversity of the phytoplankton community. Higher oligotrophic conditions in the AW were reflected by a lower value of $J^{\prime}(0.20)$ in the smaller size fraction, owing to greater dominance by cyanobacteria, whereas no significant variation in $J^{\prime}$ was observed for larger phytoplankton. Similarly, the contribution to chl a by picophytoplankton in AW was lowest among the different water masses. This was surprising, as it was expected that nutrient limitation would have a stronger impact on larger eukaryotic phytoplankton, due to their higher nutrient uptake (Fogg 1991). This small contribution may have resulted from physiological impairment of picophytoplankton, or to the use of regenerated nutrients by larger algae as indicated by the lower value of Fp. However, larger algae might have profited more than picoeukaryotes from the water mixing at the surface (which injects new nutrients from deeper layers) or from increasing turbulence, as reflected by the relative homogeneity of salinity, chl $a$ and $\mathrm{Dt} /(\mathrm{Dt}+\mathrm{Dd})$ ratio profiles.

The DCM appeared to be a favourable environment for phytoplankton, as it contained higher biomass and higher diversity. When taking the low light levels present at depth $(1 \%$ of surface irradiance at $75 \mathrm{~m})$ into consideration, algae must be well photoacclimated and their growth probably closely coupled with grazing, which is known to maintain high species diversity (Reynolds 1988). Differences in phytoplankton between the surface and the DCMs were mainly apparent in the smaller size class, which exhibited greater diversity at depth. This could be due to the limiting conditions present at the surface, in terms of nutrient concentration or excess light. However, low light intensity did not appear to limit diversification of phytoplankton community composition. For example, Prochlorococcus, which shows a high degree of genetic plasticity (Bibby et al. 2003), tolerates lower light intensities than Synechococcus, which accounts for the greater dominance of the former within the DCM. In the present study, it therefore appears that nutrient limitation was a major factor determining phytoplankton diversity, whereas light limitation did not affect the number of species present or their relative abundance.

A recurrent pattern of the DCM in the 3 water masses was the increase in the $\mathrm{Dt} /(\mathrm{Dt}+\mathrm{Dd})$ ratio paralleled by a decrease in the $\mathrm{Dd} / \mathrm{chl}$ a ratio in both size classes. This could be due to temperature stress (Brunet et al. 1992) or to chloro-respiration owing to the very low light levels available to cells, as demonstrated in culture by Jakob et al. (2001). These authors proposed that the presence of photoprotectant pigments in deep-living algae might confer an adaptive advantage in the case of rapid transport towards the surface.

\section{Phytoplankton size-related properties and diversity}

Within the phytoplankton of the area studied, size appeared to be more important than affiliation to taxonomic groups. For larger phytoplankton, the lack of correlation $(p>0.05)$ between chemotaxonomic pigment ratios and nutrient concentrations or hydrological parameters indicated a more disperse distribution among the water masses and throughout the water column.

The lack of correlation between one pigment ratio in one size class and the same ratio in the other size class indicates a discrimination of ecological niches for algae belonging to the same taxonomic group, as also suggested by higher values of $J^{\prime}$ for the larger phytoplankton. This reflects a greater homogeneity in community composition with respect to smaller phytoplankton, whose diversity is, in turn, more dependent upon environmental factors. These data, together with the lack of correlation between $J^{\prime}$ of the larger algae and any hydrological parameter or chl $a_{>3}$, demonstrated that the phytoplankton belonging to the 2 size classes were distinct and responded to different environmental cues. The larger phytoplankton appeared to be ubiquitous and, in contrast to the smaller sized phytoplankton, its use as a tracer of water masses was not possible. The lower concentration and fitness to the environment of the larger size class suggests a more 'passive' distribution and probably lower productivity rates than that of the more ecologically niche-dependent smaller algae.

For Prochlorococcus, the dvchl a cellular content was significantly different between the surface and the deeper layer (0.45 and $1.56 \mathrm{fg} \mathrm{cell}^{-1}$, respectively), which, together with observations of the 2 ecotypes shifting with depth, indicates photoadaptation by 
Prochlorococcus as a genus. The characteristics of the highly pigmented ecotype (low-light adapted) appeared to be conservative over time: it was present at the surface in the filament, whose source was upwelled waters. Our values of dvchl a per Prochlorococcus cell lie within the range of values observed by Veldhuis \& Kraay (1990) in the subtropical North Atlantic (between 0.44 and $5.14 \mathrm{fg} \mathrm{cell}^{-1}$ ) and by Morel et al. $\left(1993 ; 0.88\right.$ to $1.76 \mathrm{fg} \mathrm{cell}^{-1}$ in culture and 0.15 to $1.80 \mathrm{fg} \mathrm{cell}^{-1}$ in the tropical Atlantic). However, the lowest value of dvchl a (from the surface layer) was lower than that measured by Partensky et al. (1993) for the MED strain in culture $\left(1.21 \mathrm{fg} \mathrm{cell}^{-1}\right)$, probably due to differences in light intensities used in their study. Our estimation was drawn from a light environment ranging between 1000 and $60 \mu \mathrm{mol}$ photons $\mathrm{m}^{-2} \mathrm{~s}^{-1}$, whereas Partensky et al. (1993) used cells adapted to $133 \mu \mathrm{mol}$ photons $\mathrm{m}^{-2} \mathrm{~s}^{-1}$, which corresponds to an average depth of $35 \mathrm{~m}$ in this study. By fitting the data of dvchl a (fg cell ${ }^{-1}$ ) with relative light values from Partensky et al. (1993), and by using average light profiles obtained during this study, the light values and thus depths that corresponded to our cellular dvchl a contents could be estimated. Estimated values were 18 and $50 \mathrm{~m}$ depth for the surface and deeper layer, respectively. These figures are representative of the average depth of the surface mixed layer and DCM, respectively, and represent an indirect validation of the use of pigment cell content of phytoplankton as a marker of their light history. It also indirectly supports the method used to infer pigment cell content based on known values, despite the bias introduced by the use of pigment ratios derived from culture studies and the potential influence of genotypic variability.

Estimations of chl a content per picoeukaryote cell were highly variable, dependent upon the water mass and depth examined, and reflected the high taxonomic, ecological and physiological diversity and plasticity highlighted in previous studies (e.g. Moon-van der Staay et al. 2000, 2001, Timmermans et al. 2005). In this study, picoeukaryote chl a content varied 3- to 8fold between the upper and deeper layer. This was most probably due to a change in the picoeukaryote community composition, as reflected by a change in pigment diversity, which was higher in the DCM than in the upper layer. The different values observed in the IW and AW were probably due to the different hydrodynamics of the 2 water masses, with the IW characterized by vertical upward movements related to the onset of the vortex. The increased biomass and lower dvchl a contribution to picophytoplankton biomass in the IW indicated a trend towards an increase in cell size of phytoplankton, as reflected by the higher value of picoeukaryote chl a per cell in the DCM of IW with respect to the DCM of AW.
The pigment composition of the picoplankton was relatively unchanged in different water masses; thus, our values may be considered representative of summer conditions in the oligotrophic Mediterranean Sea in general. Changes in diversity were depth related, with light and nutrient availability probably being the most important factors. Picophytoplankton demonstrated greater ability for photoacclimation than nano- and microphytoplankton. This ability was also observed in culture (C. Brunet \& C. Dimier unpubl. data).

Prymnesiophytes (identified by $19^{\prime} \mathrm{HF}$ and chl $C_{3}$ ) showed increased vertical variability in both size classes, in agreement with the previously observed high level of diversity of this group (Moon-van der Staay et al. 2000, Zapata et al. 2004). The ratio of the 2 marker pigments $\left(19^{\prime} \mathrm{HF}\right.$ and $\left.\mathrm{chl} c_{3}\right)$ was higher in the surface layer than at depth for both size classes. The ratio $19^{\prime} \mathrm{HF} / \mathrm{chl}$ a was also different (higher at the surface), but the $\mathrm{chl} C_{3} / \mathrm{chl}$ a ratio reached maximum values deeper in the water column. This suggests photoadaptation by these algae, probably driven by chromatic adaptation to the changing light environment due to internal adjustment of the pigment pool or by species substitution. In actual fact, the chl $c_{3}$ absorption maximum is shifted towards the blue part of the spectrum when compared to 19' HF (Bidigare \& Marra 1990, Bidigare et al. 1990), and therefore the ratio of $19^{\prime} \mathrm{HF} / \mathrm{chlc} 3 \mathrm{can}$ be used as an indicator of adaption to the dim light present at depth, which is dominated by blue light.

A similar interpretation of the greater abundance of green algae in the deeper layer (Bidigare \& Marra 1990) was proposed by Glover et al. (1986), based on their photoacclimation strategy in relation to the spectral characteristics of chl $b$. In the present study, chl $b$ was one of the most abundant picoeukaryotic pigments (along with 19'BF), being more abundant at depth and representing a greater contribution to the picoplankton community (together with zeaxanthin) than to the larger size class. The different slopes of the relationship between picoeukaryote cell number and chl $b$ concentration below and above $70 \mathrm{~m}$ suggest a shift in cellular chl $b$ content, and reveals a vertical succession of cellular chl $b$ content per picoeukaryote cell, with deeper cells showing at least double the concentration of chl $b$. This confirms previous observations on the preference of these algae for deep blue waters (e.g. Bidigare \& Marra 1990, Casotti et al. 2000), where $\mathrm{chl} b$ is particularly suited to utilize the dim light available. However, we cannot assess whether our results were due to physiological adaptation and/or to species substitution. The latter seems possible, since analysis of pigment ratios revealed a niche differentiation for Prasinophytes (1 component of the chl $b$-containing 
algae). In fact, the 2 ratios - prasinoxanthin/chl $b$ and prasinoxanthin/sum of all picoeukaryotic biomarker pigments - were significantly higher in the surface layer $(<70 \mathrm{~m})$ than in the deeper layer $(>70 \mathrm{~m}$ depth, $p<0.01)$. This suggests that prasinoxanthin-containing prasinophytes were mainly present above $70 \mathrm{~m}$ depth and that vertical succession occurs within this algal group.

The data presented show that environmental factors drive the physiological responses of phytoplankton, which in turn drive changes in diversity. The approach used to obtain cellular pigment content in picoeukaryotes provides a quantitative tool to refine our vision of picophytoplankton diversity and functioning, in terms of both photoacclimation and photoadaptation, in an important area of the Mediterranean.

Acknowledgements. We thank the captain and crew of RV 'Urania' for their help during the cruise, as well as all participants of 'Symplex II'. A. Mosnier and G. Joly are kindly acknowledged for their help with HPLC analyses, as is the group headed by R. Santoleri (ISAC-CNR, Rome) for sharing hydrological data. We also thank G. Tarran and 2 anonymous referees for constructive comments made on an earlier version of the manuscript. This study represents a contribution to the aims of the Marine Biodiversity and Ecosystem Functioning (MarBEF) Network of Excellence, which is funded by the European Community's 6th Framework Programme (contract no. GOCE-CT-2003-505446). This publication is contribution number MPS-06043 of MarBEF.

\section{LITERATURE CITED}

Babin M, Morel A, Claustre H, Bricaud A, Kolber Z, Falkowski PG (1996) Nitrogen- and irradiance-dependent variations of the maximum quantum yield of carbon fixation in eutrophic, mesotrophic and oligotrophic marine systems. Deep-Sea Res I 43:1241-1272

Béranger K, Mortier L, Gasparini GP, Gervasio L, Astraldi M, Crépon M (2004) The dynamics of the Sicily Strait: a comprehensive study from observations and models. DeepSea Res II 51:411-440

Bibby TS, Mary I, Nield J, Partensky F, Barber J (2003) Lowlight adapted Prochloroccus species possess specific antennae for each photosystem. Nature 424:1051-1054

Bidigare RR, Marra J (1990) Evidence for phytoplankton succession and chromatic in the Sargasso sea during spring 1985. Mar Ecol Prog Ser 60:113-122

Bidigare RR, Ondrusek ME, Morrow J, Kiefer DA (1990) In vivo absorption properties of algal pigments. SPIE 1302 Ocean Optics X:290-302

Bohm E, Nardelli BB, Brunet C, Casotti R and 20 others (1998) SYMPLEX Experiment: first results on oceanic mesoscale dynamics and related primary production from AVHRR and SeaWifs satellite data and field expriments. EOS 5th Eur Symp Aerospace Remote Sensing, 21-24 September, Barcelona. SPIE 3496:137-148

Brunet C, Lizon F (2003) Tidal and diel periodicities of size fractionated phytoplankton pigment signatures at an offshore station in the South-Eastern English Channel. Estuar Coast Shelf Sci 56:835-845
Brunet C, Brylinski JM, Frontier S (1992) Productivity, photosynthetic pigments and hydrology in the coastal front of the Eastern English Channel. J Plankton Res 14:1541-1552

Brunet C, Casotti R, Aronne B, Vantrepotte V (2003) Measured photophysiological parameters used as tools to estimate vertical water movements in the coastal Mediterranean. J Plankton Res 25:1413-1425

Casotti R, Brunet C, Aronne B, Ribera d'Alcalà M (2000) Mesoscale features of phytoplankton and planktonic bacteria in a coastal area as induced by external water masses. Mar Ecol Prog Ser 195:15-27

Casotti R, Landolfi A, Brunet C, D'Ortenzio F and 5 others (2003) Composition and dynamics of the phytoplankton of the Ionian Sea (Eastern Mediterranean). J Geophys Res 108:8116, doi:10.1029.2002JC001541

Claustre H (1994) The trophic status of various oceanic provinces as revealed by phytoplankton pigments signature. Limnol Oceanogr 39:1207-1211

Cuttitta A, Carini V, Patti V, Bonano A and 8 others (2003) Anchovy egg and larval distribution in relation to biological and physical oceanography in the Strait of Sicily. Hydrobiologia 503:117-120

Díez B, Pedrós-Alió C, Massana R (2001) Study of genetic diversity of eukaryotic picoplankton in different oceanic regions by small-subunit rRNA gene cloning and sequencing. Appl Environ Microbiol 67:2932-2941

Díez B, Massana R, Estrada M, Pedrós-Alió C (2004) Distribution of eukaryotic picoplankton assemblages across hydrographic fronts in the Southern ocean, studied by denaturating gradient gel electrophoresis. Limnol Oceanogr 49:1022-1034

Fogg GE (1991) The phytoplanktonic ways of life. New Phytol 118:191-232

Frontier S (1985) Diversity and structure in aquatic ecosystems. Oceanogr Mar Biol Annu Rev 23:253-312

Garcia Lafuente J, Garcia A, Mazzola S, Quintanilla L, Delgado J, Cuttita A, Patti B (2002) Hydrographic phenomena influencing early life stages of the Sicilian Channel anchovy. Fish Oceanogr 11:31-44

Glover HE, Keller MD, Guillard RRL (1986) Light quality and oceanic ultraphytoplankters. Nature 319:142-143

Grasshof K (1983) Determination of nitrate. In: Grasshof K, Ehrardt K, Kremling K (eds) Methods of seawater analysis. Verlag Chemie, Weinheim, p 143-150

Huisman J, Weissing FJ (1999) Biodiversity of plankton by species oscillations and chaos. Nature 402:407-410

Jakob T, Goss R, Wilhelm C (2001) Unusual pH-dependence of diadinoxanthin de-epoxidase activation causes chlororespiration induced accumulation of diatoxanthin in the diatom Phaeodactylum tricornutum. J Plant Physiol 158: 383-390

Kana TM, Glibert PM, Goericke R, Welschmeyer NA (1988) Zeaxanthin and $\beta$-carotene in Synechococcus WH 7803 respond differently to irradiance. Limnol Oceanogr 33: 1623-1627

Karl DM, Bidigare RR, Letelier R (2001) Long term changes in plankton community struture and productivity in the North Pacific Subtropical Gyre: the domain shift hypothesis. Deep-Sea Res II 48:1449-1470

Lermusiaux PFJ, Robinson AR (2001) Features of dominant mesoscale variability, circulation patterns and dynamics in the Strait of Sicily. Deep-Sea Res I 48:1953-1997

Lindley ST, Bidigare RR, Barber RT (1995) Phytoplankton photosynthesis parameters along $140^{\circ} \mathrm{W}$ in the equatorial pacific. Deep-Sea Res Part II 42:441-463

Malanotte-Rizzoli P, Manca BB, Ribera d'Alcalà M, Theocaris A, Brenner S, Budillon G, Ozsoy E (1999) The Eastern 
Mediterranean in the 80 s and in the 90s: the big transition in the intermediate and deep circulations. Dyn Atmos Oceans 29:365-395

Moon-van der Staay SY, van der Staay GWM, Guillou L, Vaulot D (2000) Abundance and diversity of prymnesiophytes in the picoplankton community from the equatorial Pacific ocean inferred from 18S rDNA sequences. Limnol Oceanogr 45:98-109

Moon-van der Staay SY, De Wachter R, Vaulot D (2001) Oceanic 18S rDNA sequences from picoplankton reveal unsuspected eukaryotic diversity. Nature 409:607-610

Moore LR, Goericke R, Chisholm SW (1995) Comparative physiology of Synechococcus and Prochlorococcus: influence of light and temperature on growth, pigments, fluorescence and absorptive properties. Mar Ecol Prog Ser 116:259-275

Moore LR, Post AF, Rocap G, Chisholm SW (2002) Utilization of different nitrogen sources by the marine cyanobacteria Prochlorococcus and Synechococcus. Limnol Oceanogr 47:989-996

Morel A, Ahn YH, Partensky F, Vaulot D, Claustre H (1993) Prochlorococcus and Synechococcus: a comparative study of their optical properties in relation to their size and pigmentation. J Mar Res 51:617-649

Norberg J (2004) Biodiversity and ecosystem functioning: a complex adaptive systems approach. Limnol Oceanogr 49: 1269-1277

Not F, Simon N, Biegala IC, Vaulot D (2002) Application of fluorescent in situ hybridization coupled with tyramide signal amplification (FISH-TSA) to assess eukaryotic picoplankton composition. Aquat Microb Ecol 28: 157-166

Not F, Massana R, Latasa M, Marie D and 5 others (2005) A late summer community composition and abundance of photosynthetic picoeukaryotes in Norwegian and Barents Sea. Limnol Oceanogr 50:1677-1686

Olaizola M, Ziemann DA, Bienfang PK, Walsh WA, Conquest LD (1993) Eddy-induced oscillations of the pycnocline affect the floristic composition and depth distribution of phytoplankton in the sub-tropical Pacific. Mar Biol 116: 533-542

Olson RJ, Zettler ER, DuRand MD (1993) Phytoplankton analysis using flow cytometry. In: Kemp PF, Sherr BF, Sherr EB, Cole JJ (eds) Handbook of methods in aquatic microbial ecology. Lewis Publishers, Boca Raton, FL, p 175-186

Partensky F, Hoepffner N, Li WKW, Ulloa O, Vaulot D (1993) Photoacclimation of Prochlorococcus sp. (Prochlorophyta) strains isolated from the north Atlantic and the Mediterranean Sea. Plant Physiol 101:285-296

Editorial responsibility: William K. W. Li, Dartmouth, Nova Scotia, Canada
Pemberton K, Rees AP, Miller PI, Raine R, Joint I (2004) The influence of water body characteristics on phytoplankton diversity and production in the Celtic Sea. Cont Shelf Res 24:2011-2028

Prézelin BB, Tilzer MM, Schofield O, Haese C (1991) The control of the production process of phytoplankton by the physical structure of the aquatic environment with special reference to its optical properties. Aquat Sci 53:136-186

Reynolds CS (1988) The concept of ecological succession applied to seasonal periodicity of freshwater phytoplankton. Verh Int Ver Limnol 23:683-691

Timmermans KR, van der Wagt B, Veldhuis MJW, Maatman A, de Baar HJW (2005) Physiological responses of three species of marine pico-phytoplankton to ammonium, phosphate, iron and light limitation. J Sea Res 53:109-120

Vaillancourt RD, Marra J, Seki MP, Parsons ML, Bidigare RR (2003) Impact of a cyclonic eddy on phytoplankton community structure and photosynthetic competency in the subtropical North Pacific Ocean. Deep-Sea Res II 50: 829-847

Veldhuis MJW, Kraay GW (1990) Vertical distribution and pigment composition of a picoplanktonic prochlorophyte in the subtropical North Atlantic: a combined study of HPLC-analysis of pigments and flow cytometry. Mar Ecol Prog Ser 68:121-127

Veldhuis MJW, Kraay GW (2004) Phytoplankton in the subtropical Atlantic ocean: towards a better assessment of biomass and composition. Deep-Sea Res I 51:507-530

Vidussi F, Claustre H, Bustillos-Guzman J, Caillau C, Marty JC (1996) Determination of chlorophylls and carotenoids of marine phytoplankton: separation of chlorophyll a from divinyl-chlorophyll $a$ and zeaxanthin from lutein. J Plankton Res 18:2377-2382

Vidussi F, Claustre H, Manca BB, Luchetta A, Marty JC (2001) Phytoplankton pigment distribution in relation to upper thermocline circulation in the Eastern Mediterranean Sea during winter. J Geophys Res 106:19939-19956

Weithoff G, Walz N, Gaedke U (2001) The intermediate disturbance hypothesis-species: diversity or functional diversity? J Plankton Res 23:1147-1155

Zapata M, Jeffrey SW, Wright SW, Rodriguez F, Garrido JL, Clementson L (2004) Photosynthetic pigments in 37 species (65 strains) of Haptophyta: implications for oceanography and chemotaxonomy. Mar Ecol Prog Ser 270:83-102

Zingone A, Borra M, Brunet C, Forlani G, Kooistra W, Procaccini G (2002) Phylogenetic position of Crustomastix stigmatica sp nov and Dolichomastix tenuilepis, in relation to the Mamiellales (Prasinophyceae, Chlorophyta). J Phycol 38:1024-1035

Submitted: October 19, 2005; Accepted: June 6, 2006

Proofs received from author(s): September 5, 2006 